\title{
EVALUASI TERHADAP PERATURAN BERSAMA MENTERI TAHUN 2006 TENTANG PENDIRIAN RUMAH IBADAH
}

\author{
Binsar A. Hutabarat \\ Reformed Center for Religion and Society
}

\begin{abstract}
This article with a title "Evaluation to the Joint Regulation of Ministers in 2006 about the Establishment of a House of Worship" will focus on the evaluation of the formulation of the Joint Regulation of Ministers in 2006 about the Establishment of a House of Worship (Peraturan Bersama Menteri - PBM), as well as the evaluation of the application and impact of the enacted regulation. The research methodology uses qualitative research with an in-depth interview to some church leaders in Bekasi, West Java who are directly connected with the enactment of this regulation, and also research to the related documents with the PBM, especially the policy which founded the PBM. The research finding is that the formulation of the Joint Regulation of Ministers about the Establishment of a House of Worship has not yet fitted with the formulation policy model of a democratic country so that its application is not in accordance with the expected goal. PBM application gives negative impact to the inter-religious harmony in Indonesia.
\end{abstract}

KEYWORDS: regulation of the establishment of a house of worship, freedom of worship, policy evaluation

ABSTRAK: Artikel yang berjudul "Evaluasi terhadap Peraturan Bersama Menteri Tahun 2006 tentang Pendiriran Rumah Ibadah" ini akan fokus pada evaluasi formulasi Peraturan Bersama Menteri Tahun 2006 tentang Pendirian Rumah Ibadah (PBM), serta evaluasi penerapannya dan dampak dari diberlakukannya peraturan tersebut. Metode penelitian yang digunakan adalah penelitian kualitatif dengan wawancara mendalam kepada sejumlah pimpinan gereja di Bekasi, Jawa Barat yang terkait langsung dengan 
pelaksaan peraturan tersebut, dan juga penelitian terhadap dokumendokumen terkait dengan PBM, secara khusus kebijakan yang melandasi PBM. Temuan penelitian ini adalah formulasi Peraturan Bersama Menteri tentang Pendirian Rumah Ibadah belum sesuai dengan model perumusan kebijakan negara demokratis, sehingga penerapannya tidak sesuai dengan tujuan yang diharapkan. Penerapan PBM berdampak buruk terhadap kerukunan antarumat beragama di Indonesia.

KATA-KATA KUNCI: peraturan pendirian rumah ibadah, kebebasan beribadah, evaluasi kebijakan.

\section{Pendahuluan}

Indonesia adalah negara dengan masyarakat yang amat plural baik dalam hal suku, budaya, dan agama. Proteksi kebebasan beragama dalam negara yang sangat plural seperti Indonesia ini membutuhkan kebijakan yang unggul dan non-diskriminatif. Sebaliknya, hadirnya kebijakankebijakan yang buruk dan diskriminatif akan menyebabkan timbulnya ketidakadilan, yang akhirnya bermuara pada konflik antaragama. Apabila pemerintah Indonesia gagal membuat kebijakan yang unggul dalam bidang kehidupan antaragama di Indonesia, maka taruhannya adalah disintegrasi bangsa yang mengancam keutuhan bangsa Indonesia. Kebijakan yang diskriminatif akan berdampak panjang, yakni kian menipisnya toleransi antarumat beragama di Indonesia. Indonesia hanya bisa menjadi bangsa yang toleran dan terus memelihara toleransi antaragama jika kebijakan yang dihasilkan terkait dengan kehidupan bersama agama-agama adalah kebijakan-kebijakan yang unggul dan tentu saja dapat diimplementasikan. ${ }^{6}$

Salah satu produk undang-undang yang menimbulkan kontroversi terkait dengan kehidupan bersama agama-agama adalah Surat Keputusan (SK) Menteri Agama dan Menteri Dalam Negeri Nomor: 01/BER/MDN-

\footnotetext{
6 Riant Nugroho, Public Policy (Jakarta: PT Gramedia, 2009), 39.
} 
MAG/1969 tentang Pelaksanaan Tugas Aparatur Pemerintahan dalam Menjamin Ketertiban dan Kelancaran Pelaksanaan Pengembangan dan Ibadat Agama oleh Pemeluk-pemeluknya. Dalam pasal 4 ayat 1 perundangundangan tersebut dijelaskan bahwa pendirian rumah ibadah perlu mendapat izin dari kepala daerah atau pejabat pemerintah di bawahnya yang dikuasakan untuk itu. Latar belakang dikeluarkannya SK tersebut karena ada gejala-gejala bahwa dalam beberapa daerah, jumlah umat Kristen bertambah dengan pesat, dan di beberapa daerah terjadi aksi perusakan terhadap gedung gereja. ${ }^{7}$ SKB Dua Menteri ini pada masa reformasi mengalami perubahan menjadi Peraturan Bersama Menteri (PBM) dalam Peraturan Bersama Menteri Agama dan Menteri Dalam Negeri Nomor 9 Tahun 2006, dan Nomor 8 Tahun 2006. Namun, inti dari PBM tersebut tidak berbeda dari SKB yang membatasi kebebasan beragama, khususnya pembangunan tempat ibadah yang menuntut adanya sejumlah 60 (enam puluh) tanda tangan orang dewasa dari masyarakat di mana tempat ibadah itu akan didirikan. Untuk pendirian gereja, sekurangkurangnya diajukan oleh 90 orang anggota dewasa. ${ }^{8}$

Kajian ini secara khusus akan mengevaluasi struktur dan rumusan Peraturan Bersama Menteri (PBM) tentang pendirian rumah ibadah, serta meneliti faktor-faktor yang mempengaruhi penerapan PBM. Penelitian penerapan PBM ini secara khusus dilakukan di Bekasi. Karena kebijakan yang unggul pastilah dapat diimplementasikan untuk membawa pada kehidupan beragama yang lebih harmonis. Sebuah kebijakan yang tidak dapat diimplementasikan dengan baik pastilah terkait dengan isi rumusan kebijakan tersebut.

\section{Kajian Teori}

Kebijakan Publik Kebebasan Beragama dan Pendirian Rumah Ibadah

\footnotetext{
7 Ibid.

8 Bahan Rapat Konsultasi Pimpinan Lembaga Persekutuan Gerejawi Aras Nasional dengan Pemerintah Pusat tentang Implementasi Peraturan Bersama No. 9 dan 8 Tahun 2006 (Jakarta, 2008).
} 
Wayne Parsons berujar, kebijakan (policy) adalah istilah yang tampaknya banyak disepakati bersama, "dalam penggunaan yang umum", istilah kebijakan dianggap berlaku untuk sesuatu yang 'lebih besar' ketimbang keputusan tertentu, tetapi lebih kecil ketimbang gerakan sosial." 9 Sejalan dengan Parsons, mengenai istilah kebijakan Budi Winarno berpendapat, secara umum istilah "kebijakan" atau "policy" digunakan untuk menunjuk perilaku seorang aktor (misalnya seorang pejabat, suatu kelompok, maupun suatu lembaga pemerintah) atau sejumlah aktor dalam suatu bidang tertentu."10 Selanjutnya Winarno menjelaskan, pengertian kebijakan seperti di atas hanya memadai untuk keperluan pembicaraan biasa atau umum, namun menjadi kurang memadai untuk pembicaraanpembicaraan yang lebih bersifat ilmiah dan sistematis menyangkut analisis kebijakan publik. ${ }^{11}$

Secara lebih detail Wayne Parsons menerangkan mengenai istilah kebijakan seperti berikut:

Makna modern dari gagasan "kebijakan" dalam bahasa Inggris adalah seperangkat aksi atau rencana yang mengandung tujuan politik yang berbeda dengan makna "administration". Yang lebih penting khususnya sejak periode pasca-Perang Dunia II, kata policy mengandung makna kebijakan sebagai sebuah rationale, sebuah manifestasi dari penilaian yang penuh pertimbangan... Sebuah kebijakan adalah usaha untuk mendefinisikan dan menyusun basis rasionale untuk melakukan atau tidak melakukan sesuatu. ${ }^{12}$

\footnotetext{
9 Wayne Parsons, Public Policy (Jakarta: Kencana, 2006), 14.

10 Budi Winarno, Kebijakan Publik: Teori, Proses, dan Studi Kasus (Jakarta: Center of Academic Publishing Service, 2007), 19.

11 Ibid.

12 Wayne Parsons, op. cit., 15. Parsons mengutip Hogwood dan Gunn menyebutkan sepuluh penggunaan istilah kebijakan dalam pengertian modern antara lain: sebagai label untuk sebuah bidang aktivitas, sebagai ekspresi tujuan umum atau aktivitas negara yang diharapkan, sebagai proposal spesifik, sebagai keputusan pemerintah, sebagai otorisasi formal, sebagai sebuah program, sebagai sebuah output, sebagai "hasil" atau outcome, sebagai teori atau model, sebagai sebuah proses.
} 
Makna kata "kebijakan" harus dipahami dalam konteks historis, makna kebijakan yang senantiasa berubah menunjukkan perubahanperubahan dalam praktik kebijakan. Pada awalnya istilah "kebijakan" atau pokok-pokok platform menjadi rasionalitas politik. Mempunyai kebijakan berarti memiliki alasan atau argumen yang mengandung klaim bahwa pemilik kebijakan memahami persoalan beserta solusinya. Kebijakan dalam hal ini mengemukakan apa yang sedang terjadi dan apa yang seharusnya dilakukan. Artinya, sebuah kebijakan memberikan semacam teori yang mendasari klaim legitimasi. Selanjutnya, dengan berkembangnya sistem partai dan pemilu modern di masyarakat industri, diskursus kebijakan kemudian menjadi sarana utama bagi elektorat untuk terlibat dalam kegiatan "politik" dan persaingan elite politik. Politisi diharapkan punya "kebijakan" sebagaimana halnya sebuah toko mesti mempunyai barang dagangan. Kebijakan merupakan "mata uang" penting dalam perdagangan demokratik. ${ }^{13}$

Gagasan kebijakan sebagai "produk" atau "prinsip" kemudian berkembang menjadi istilah dalam konotasi netral seperti dinyatakan oleh Lasswell: “Kata 'kebijakan' (policy) umumya dipakai untuk menunjukkan pilihan terpenting yang diambil baik dalam kehidupan organisasi atau privat."14 Jadi Lasswell tidak membatasi penggunaan istilah kebijakan hanya dalam area politik saja, menurutnya, "Kebijakan" bebas dari konotasi yang dicakup dalam kata politis (political) yang sering kali diyakini mengandung makna "keberpihakan" dan korupsi."15

Meskipun belum ada kesepakatan apakah "policy" diterjemahkan menjadi, "kebijakan" atau "kebijaksanaan" akan tetapi tampaknya kecenderungan "policy" diterjemahkan menjadi kebijakan, oleh karena itu "public policy" diterjemahkan dengan kebijakan publik. ${ }^{16}$

\footnotetext{
13 Ibid., 16.

14 Ibid., 17.

15 Ibid., 17.

16 Lembaga Administrasi Negara, Analisis Kebijakan Publik (Jakarta: Lembaga Administrasi Negara Republik Indonesia, 2008), 4.
} 
Menurut Tilaar dan Nugroho istilah kebijakan publik mempunyai banyak pemahaman teoritis ${ }^{17}$, yang dirumuskannya demikian:

Kebijakan publik adalah keputusan yang dibuat oleh negara, khususnya pemerintah, sebagai strategi untuk merealisasikan tujuan dari negara yang bersangkutan. Kebijakan publik adalah strategi untuk mengantar masyarakat pada masa awal, memasuki masyarakat transisi, untuk menuju kepada masyarakat yang dicita-citakan. ${ }^{18}$

Berdasarkan definisi di atas jelaslah bawa kebijakan publik merupakan upaya yang dilakukan pemerintah untuk menyelesaikan permasalahan publik. Thomas R. Dye merangkum dari definisi-definisi mengenai kebijakan publik demikian: "Public policy is whatever governments choose to do or not to do"19 (kebijakan publik adalah apapun pilihan pemerintahan untuk melakukan sesuatu atau tidak melakukan). ${ }^{20}$ Bagi Dye pusat perhatian kebijakan publik tidak hanya pada apa yang dilakukan pemerintah, melainkan termasuk juga apa saja yang tidak dilakukan oleh pemerintah. Karena hal-hal yang tidak dilakukan pemerintah mempunyai dampak yang cukup besar terhadap masyarakat seperti halnya dengan tindakan-tindakan yang dilakukan oleh pemerintah. ${ }^{21}$

Berdasarkan definisi-definisi di atas, jelaslah bahwa kebijakan publik mempunyai beberapa implikasi sebagaimana ditegaskan Anderson, kebijakan publik berorientasi pada maksud atau tujuan, bukan perilaku

17 H.A.R. Tilaar dan Rian Nugroho, Kebijakan Pendidikan (Yogyakarta: Pustaka pelajar, 2009), 183-4.

18 Ibid., 184-5.

19 Thomas R. Dye, Understanding Public Policy (United States: Prentice Hall, 1978), 1. Thomas Dye menjelaskan: More elaborate definition of public policy are found in literature, of course, but on examination they seem to boil down to the same thing. David Easton defines public policy as "the authoritative allocation of values for the whole society" but it turns out that only the government can authoritatively act on the whole society, and everything the government choose to do or not to do results in the whole allocation of values. Laswell and Kaplan defines policy "as a projected program of goals, value, and practices" and Carl Friedrich says, it is essential.

$20 \quad$ Ibid., 35.

21 Lihat, Irawan Suntoro dan Hasan Hariri, Kebijakan Publik (Yogyakarta: Graha Ilmu, 2015), 3. 
serampangan. Kebijakan publik bukan sesuatu yang berlaku begitu saja, melainkan direncanakan oleh aktor-aktor politik yang terlibat dalam sistem politik. Kebijakan merupakan arah atau pola tindakan yang dilakukan oleh pejabat-pejabat pemerintah, bukan merupakan keputusan-keputusan tersendiri. Suatu kebijakan mencakup tidak hanya keputusan untuk menetapkan undang-undang mengenai suatu hal, tetapi juga keputusankeputusan beserta dengan pelaksanaannya. Dan kebijakan adalah apa yang sebenarnya dilakukan oleh pemerintah dalam mengatur persoalanpersoalan publik misalnya terkait dengan kehidupan beragama, demikian juga perihal pendirian rumah ibadah. Kebijakan publik mungkin dalam bentuknya bersifat positif dan negatif. Secara positif, kebijakan, mungkin mencakup bentuk tindakan pemerintah yang jelas untuk untuk mempengaruhi suatu masalah tertentu. Secara negatif, kebijakan mungkin mencakup suatu keputusan oleh pejabat-pejabat pemerintah, tetapi tidak untuk mengambil keputusan tindakan dan tidak untuk melakukan sesuatu mengenai suatu persoalan yang memerlukan keterlibatan pemerintah. Dengan kata lain, pemerintah dapat mengambil kebijakan untuk tidak melakukan campur tangan dalam bidang-bidang umum maupun khusus. Kebijakan tidak campur tangan mungkin mempunyai konsekuensikonsekuensi besar terhadap masyarakat atau kelompok-kelompok masyarakat. Dalam bentuknya yang positif, kebijakan publik didasarkan pada undang-undang dan bersifat otoritatif. ${ }^{22}$

Kebijakan publik ini adalah jalan bagi pemerintah Indonesia untuk mencapai apa yang dicita-citakan seluruh rakyat Indonesia, yaitu terwujudnya suatu masyarakat yang adil dan makmur. Sedang dalam bidang kehidupan beragama, kebijakan publik adalah pedoman bagaimana negara mencapai apa yang diperintahkan Pasal 29 UUD 1945 tentang Kebebasan Beragama. (1) Negara berdasar atas Ketuhanan Yang Maha Esa. (2) Negara menjamin kemerdekaan tiap-tiap penduduk untuk memeluk agamanya masing-masing dan untuk beribadat menurut agamanya dan

22 Budi Winarno, op. cit., 23-4. 
kepercayaannya itu. Pemerintah mendapatkan mandat rakyat untuk memberikan proteksi terhadap kebebasan beragama, kebebasan beribadat baik secara pribadi maupun secara berkelompok dalam sebuah rumah ibadat.

Kebijakan perlindungan terhadap kebebasan beragama dan berkeyakinan secara tegas ditetapkan dalam UUD RI. Kebijakan tersebut mesti menjadi pedoman bagi peraturan-peraturan di bawahnya. Kebijakan perlindungan kebebasan beragama secara langsung mensyaratkan adanya hak kebebasan mendirikan rumah ibadah sesuai dengan agama dan kepercayaan. Hak menjalankan ibadah dan mendirikan rumah ibadah ini tergolong kategori hak yang dapat dibatasi (derogable right). Pembatasan tersebut menurut Deklarasi Universal HAM pasal 18 ayat (2) berbunyi seperti berikut:

Kebebasan menjalankan dan menentukan agama atau kepercayaan seseorang hanya dapat dibatasi oleh ketentuan berdasarkan hukum, dan yang diperlukan untuk melindungi keamanan, ketertiban, kesehatan, atau moral masyarakat, atau hak-hak kebebasan mendasar orang lain. Perserikatan Bangsa-Bangsa secara khusus menjamin adanya perlindungan atas rumahrumah ibadah yang digunakan oleh warga. Hak untuk membangun rumah ibadah merupakan perwujudan dari kebebasan beragama atau berkeyakinan, sebagaimana hak untuk menggunakan dan memasang simbol agama/keyakinan, dan menjalankan hari libur keagamaan/keyakinan. ${ }^{23}$

Selain dokumen DUHAM 1948, Kovenan Internasional Hak-Hak Sipil dan Politik, ada dua dokumen lain yang dideklarasikan PBB, dan dokumendokumen tersebut menyediakan standar-standar internasional yang diakui secara luas, serta dapat digunakan sebagai rujukan untuk menyelesaikan masalah-masalah HAM.

Pertama adalah dokumen Deklarasi untuk Mengeliminasi Segala Bentuk Praktik Intoleransi dan Diskriminasi Berdasarkan Agama dan Kepercayaan (Declration on elimination of All Forms Intolerance and

23 Ibid, 19. 
Discrimination Based on Religion or Belief). Pasal 2 Deklarasi ini mewajibkan negara untuk mengambil tindakan efektif dalam mencegah atau menghapus praktik diskriminasi berbasis agama dan keyakinan. Bahkan negara juga memiliki kewajiban untuk membatalkan setiap produk perundangundangan yang berisi pesan diskriminasi.

Kedua, dokumen Deklarasi untuk Melindungi Hak-Hak Individu Minoritas untuk Bidang Nasionalitas/Etnis, Agama, dan Bahasa (Declaration on the Rights of Persons Belonging to National or Ethnic, Religious and Linguistic Minorities). Pasal 4 ayat (2) Deklarasi tersebut menyatakan negara juga berkewajiban untuk memberikan perlindungan bagi individu-individu minoritas agar mereka bisa menjalankan ritual agamanya dengan bebas. Negara juga berkewajiban untuk mengambil tindakan efektif untuk menciptakan iklim kondusif agar individu-individu minoritas dapat menjalankan ibadahnya dengan baik. ${ }^{24}$

Arti penting sebuah rumah ibadah untuk menjalankan ibadah secara bersama-sama itulah yang membuat pemerintah Indonesia pada awalnya tidak mewajibkan pengurusan izin pendirian rumah ibadah, apalagi pada awalnya daerah-daerah di Indonesia umumnya bersifat homogen. Namun, dengan berjalannya waktu, dan perpindahan penduduk yang makin tinggi, maka daerah-daerah di Indonesia menjadi lebih heterogen, dan hadirlah persoalan terkait dengan pendirian rumah ibadah.

Untuk mengatasi konflik tentang pendirian rumah ibadah pemerintah Indonesia mengeluarkan peraturan tentang pendirian rumah ibadah. Peraturan tentang pendirian rumah ibadah ini pertama kali dikeluarkan pada tahun 1969 dalam bentuk Surat Keputusan Bersama (SKB) Menteri Agama dan Menteri Dalam Negeri Nomor 01/BER/MDN/1969 tentang Pelaksanaan Tugas Aparatur Pemerintahan dalam Menjamin Ketertiban dan Kelancaran Pelaksanaan Pengembangan dan Ibadat oleh Pemelukpemeluknya.

24 Ibid, 20. 
Terbitnya SKB tersebut ternyata kemudian dijadikan instrumen bagi penutupan gereja di berbagai tempat. Dengan alasan itu kemudian pemerintah merevisi SKB tersebut menjadi PBM No. 9/2006 dan 8/2006 dan di dalamnya juga mengatur pendirian rumah ibadah. PBM memang memiliki perbedaan dengan SKB, namun keduanya memiliki persamaan. Yakni mensyaratkan keharusan pengurusan izin rumah ibadah.

\section{Metode Penelitian}

Metode yang digunakan dalam penelitian ini adalah metode penelitian kualitatif. Metode kualitatif ini digunakan dengan alasan karena masalah-masalah penelitian perlu digali untuk mendapatkan sebuah pengertian yang mendalam. ${ }^{25}$ Data kualitatif ini memungkinkan pembaca mendapatkan pemahaman yang melampaui angka-angka dan statistik inferensi. ${ }^{26}$ Teknik pengumpulan data kualitatif dilakukan dengan menggunakan teknik kondisi yang alami, sumber data primer, dan teknik observasi, wawancara mendalam, dan dokumentasi. ${ }^{27}$ Teknik pengumpulan data yang digunakan dalam penelitian evaluasi ini adalah wawancara (interview) untuk mengetahui hal-hal yang lebih mendalam dari responden. ${ }^{28}$ Teknik yang digunakan adalah wawancara tidak terstruktur untuk mendapatkan informasi yang lebih mendalam. ${ }^{29}$

Teknik analisis data kualitatif secara tipikal mengikuti langkahlangkah pengumpulan data yang dikumpulkan ke dalam kategori-kategori informasi yang disusun. Teknik pengumpulan data secara kualitatif menggunakan teknik triangulasi, artinya pengumpulan data dilakukan

\footnotetext{
25 John W. Creswell, Educational Research (Boston: Pearson, 2012), 16-8.

26 Patricia J. Rogers, Delwyn Goodrick, “Qualitative Data Analysis” dalam Joseph S. Wholey, et. al., Hand Book of Program Evaluation (San Francisco: Jossey-Bass, 2010), 429.

27 M. Djunaidi Ghony dan Fauzan Almanshur, Metodologi Penelitian Kualitatif (Yogyakarta: ArRuzz Media, 2012), 164.

28 Sugiyono, Metode Penelitian Pendidikan (Bandung: Alfa Beta, 2012), 194.

29 Ibid.
} 
secara terus-menerus sampai mendapatkan data jenuh.

Selanjutnya, mengenai teknik analisis data kualitatif ini dilakukan dengan menyusun data yang telah dikumpulkan melalui wawancara, catatan lapangan, dan bahan-bahan lain secara sitematis agar temuan tersebut dapat menjadi bahan informasi. Analisis data dilakukan dengan mengorganisir data berupa informasi itu, menjabarkannya dalam unit-unit dengan melakukan sintesa, kemudian menyusun dalam pola, memilih yang penting untuk dipelajari, dan kemudian dibuat kesimpulan.

\section{Hasil Penelitian}

\section{Evaluasi Struktur PBM tentang Pendirian Rumah ibadat}

Berdasarkan konsiderans menimbang dari Peraturan Bersama Menteri Agama dan Menteri Dalam Negeri tentang Pedoman Pelaksanaan Tugas Kepala Daerah/Wakil Kepala daerah dalam Pemiliharaan Kerukunan Umat beragama, Pemberdayaan Forum Kerukunan Umat Beragama, dan Pendirian Rumah Ibadat dijelaskan:

a. bahwa hak beragama adalah hak asasi manusia yang tidak dapat dikurangi dalam keadaan apapun; b. bahwa setiap orang bebas memilih agama dan beribadat menurut agamanya; c. bahwa negara menjamin kemerdekaan tiap-tiap penduduk untuk memeluk agamanya masingmasing dan untuk beribadat menurut agamanya dan kepercayaannya itu; d. bahwa pemerintah berkewajiban melindungi setiap usaha penduduk melaksanakan ajaran agama dan ibadat pemeluk-pemeluknya, sepanjang tidak bertentangan dengan peraturan perundang-undangan, tidak menyalahgunakan atau menodai agama, serta tidak mengganggu ketenteraman dan ketertiban umum; e. bahwa pemerintah mempunyai tugas untuk memberikan bimbingan dan pelayanan agar setiap penduduk dalam melaksanakan ajaran agamanya dapat berlangsung dengan rukun, lancar, dan tertib; f. bahwa arah kebijakan pemerintah dalam pembangunan nasional di bidang agama antara lain peningkatan kualitas pelayanan dan pemahaman agama, kehidupan beragama, serta peningkatan kerukunan intern dan antarumat beragama; g. bahwa daerah dalam rangka 
menyelenggarakan otonomi, mempunyai kewajiban melaksanakan urusan wajib bidang perencanaan, pemanfaatan, dan pengawasan tata ruang serta kewajiban melindungi masyarakat, menjaga persatuan, kesatuan, dan kerukunan nasional serta keutuhan Negara Kesatuan Republik Indonesia; h. bahwa kerukunan umat beragama merupakan bagian penting dari kerukunan nasional; i. bahwa kepala daerah dan wakil kepala daerah dalam rangka melaksanakan tugas dan wewenangnya mempunyai kewajiban memelihara ketenteraman dan ketertiban masyarakat; j. bahwa Keputusan Bersama Menteri Agama dan Menteri Dalam Negeri Nomor 01/BER/MDNMAG/1969 tentang Pelaksanaan Tugas Aparatur Pemerintahan dalam Menjamin Ketertiban dan Kelancaran Pelaksanaan Pengembangan dan Ibadat Agama oleh Pemeluk-pemeluknya untuk pelaksanaannya di daerah otonom, pengaturannya perlu mendasarkan dan menyesuaikan dengan ketentuan peraturan perundang-undangan; 30

Alasan dari diterbitkannya PBM tentang Pendirian Rumah Ibadah adalah bisa dilihat dalam pasal 29 UUD 1945 tentang kebebasan beragama. Jadi terbitnya PBM adalah untuk melaksanakan kebijakan negara yang dituangkan dalam UUD 1945 karena belum ada UU turunan dari UUD tentang kebebasan beragama.

Selanjutnya, dalam konsiderans mengingat ditetapkan seperti berikut: 1. Undang-Undang Penetapan Presiden Nomor 1 Tahun 1965 tentang Pencegahan Penyalahgunaan dan/atau Penodaan Agama (Lembaran Negara Republik Indonesia Tahun 1965 Nomor 3, Tambahan Lembaran Negara Republik Indonesia Nomor 2726); 2. Undang-Undang Nomor 8 Tahun 1985 tentang Organisasi Kemasyarakatan (Lembaran Negara Republik Indonesia Tahun 1985 Nomor 44, Tambahan Lembaran Negara Republik Indonesia Nomor 3298); 3. Undang-Undang Nomor 39 Tahun

30 Peraturan Bersama Menteri Agama dan Menteri Dalam Negeri tentang Pedoman Pelaksanaan Tugas Kepala Daerah/Wakil Kepala daerah dalam Pemiliharaan Kerukunan Umat beragama, Pemberdayaan Forum Kerukunan Umat Beragama, dan Pendirian Rumah Ibadat. 
1999 tentang Hak Asasi Manusia (Lembaran Negara Republik Indonesia Tahun 1999 Nomor 165, Tambahan Lembaran Negara Nomor 3886); 4. Undang-Undang Nomor 28 Tahun 2002 tentang Bangunan Gedung (Lembaran Negara Republik Indonesia Tahun 2002 Nomor 134, Tambahan Lembaran Negara Republik Indonesia Nomor 4247); 31

Konsiderans mengingat adalah dasar hukum dari dikeluarkannya PBM tentang pendirian rumah ibadah. Dasar hukum yang pertama adalah Undang-Undang Penetapan Presiden Nomor 1 tahun 1965 tentang Pencegahan Penyalahgunaan dan/atau Penodaan Agama. Sedang Penetapan Presiden menurut Undang-Undang No 10 Tahun 2004 tentang Pembentukan Peraturan Perundang-undangan Pasal 10 menjelaskan bahwa "Materi muatan Peraturan Pemerintah berisi materi untuk menjalankan undangundang sebagaimana mestinya." 32 Dengan demikian karena UUD 45 tentang kebebasan beragama belum diturunkan dalam undang-undang di bawahnya, maka jelaslah bahwa landasan PBM adalah UUD 1945 tentang kebebasan beragama, maka dengan demikian dapat dipahami PBM merupakan pedoman pelaksanaan penunaian kebebasan beribadat secara berkelompok dalam hal pendirian rumah ibadat sebagaimana tertuang dalam UUD 1945 tentang kebebasan beragama. Artinya, Pedoman pelaksanaan UUD 1945 tentang kebebasan beragama dan beribadat yang dituangkan dalam PBM tidak boleh bertentangan dengan UUD 1945 yang menjamin kebebasan mendirikan rumah ibadat, serta beribadah secara berkelompok. PBM bukan kebijakan yang dapat membatasi pendirian kebebasan beribadat yang dijamin dalam konstitusi Republik Indonesia.

Struktur PBM dapat dipahami dalam perundang-undangan Republik Indonesia dengan melihat pada Undang-Undang No 10 Tahun 2004 tentang Pembentukan Peraturan Perundang-undangan. Pasal 7 Undang-undang tersebut mengatur perihal jenis dan hierarki Peraturan Perundang-

\footnotetext{
31 Ibid.

32 Lihat juga, Undang-undang Republik Indonesia Nomor 12 Tahun 2011 tentang pembentukan Peraturan Perundang-undangan.
} 
undangan yang adalah sebagai berikut: ${ }^{33}$

a. Undang-Undang Dasar Negara Republik Indonesia Tahun 1945;

b. Undang-Undang/Peraturan Pemerintah Pengganti Undang-Undang;

c. Peraturan Pemerintah;

d. Peraturan Presiden;

e. Peraturan Daerah

Karena PBM dilandaskan pada ketetapan presiden, dan ketetapan presiden bertujuan melaksanakan undang-undang, sedangkan penjabaran UUD 1945 belum dijabarkan dalam undang-undang di bawahnya, maka dapat dipahami bahwa PBM adalah pedoman untuk melaksanakan UUD 1945, secara khusus tentang kebebasan beragama dan kebebasan menjalankan ibadah menurut agama masing masing.

\section{Evaluasi Formulasi PBM}

Proses formulasi PBM dapat diketahui bahwa peraturan ini merupakan hasil interaksi di antara institusi-institusi negara, seperti layaknya jenis kebijakan kontinentalis. Berbeda dengan kebijakan AngloSaxon yang memahami kebijakan publik sebagai turunan politik demokrasi, dan melihat kebijakan publik sebagai sebuah interaksi antara negara rakyat (publik). ${ }^{34}$ Dengan demikian dapat dipahami bahwa model perumusan PBM yang elitis, inkrementalis ini, tidak sesuai dengan konstitusi negeri ini yang menetapkan Indonesia sebagai negara demokrasi. Mestinya model rumusan PBM sebuah negara demokratis seperti Indonesia mengadopsi model kebijakan publik yang demokratis, dengan melibatkan semua stakeholder. Dengan demikian jelaslah bahwa formulasi PBM tidak benar dalam proses formulasinya. Formulasi PBM yang tidak melibatkan semua stakeholder

\footnotetext{
33 Undang-Undang No 10 Tahun 2004 tentang Pembentukan Peraturan Perundang-undangan Pasal 7. Lihat juga, Undang-undang Republik Indonesia Nomor 12 Tahun 2011 tentang pembentukan Peraturan Perundang-undangan.

34 Riant Nugroho, Public Policy, op. cit., 22.
} 
khususnya komunitas-komunitas agama membuat formulasi PBM tersebut tidak transparan. Bahkan penetapannya masih menimbulkan kontroversi. Pada awal ditetapkannya peraturan tersebut, Gomar Gultom, sekretaris umum Persekutuan Gereja-gereja di Indonesia (PGI) pernah mengatakan, "Kendati PBM tidak sesuai dengan prinsip-prinsip HAM, terutama kebebasan beribadah, PBM diharapkan bisa membantu masyarakat Indonesia yang sangat majemuk untuk menjalankan ibadah dengan baik". 35 Mengutip apa yang diungkapkan Andreas A. Yewangoe, yang pada saat diterbitkannya PBM menjabat sebagai ketua umum PGI, Gomar Gultom selanjutnya menegaskan, "Kalau ternyata PBM ini lebih melancarkan pembangunan gedung-gedung ibadah sebagai wujud kerukunan otentik di antara warga, maka ia telah menjadi berkat bagi negeri ini. Kalau sebaliknya, maka PBM ini mesti ditinjau kembali, bahkan dicabut." 36

Pemahaman yang beragam terhadap rumusan PBM mengindikasikan bahwa kebijakan elitis tersebut lemah dalam sosialisasi. Akibatnya implementasi PBM bukannya melindungi kebebasan beribadat, sebaliknya dijadikan instrumen untuk menutup rumah-rumah ibadat yang belum memiliki izin, dan dijadikan alat untuk mempersulit komunitas agama tertentu untuk memiliki rumah ibadat.

Perlunya izin khusus pendirian rumah ibadah di Indonesia berawal dengan diterbitkannya Surat Keputusan (SK) Menteri Agama dan Menteri Dalam Negeri Nomor: 01/BER/MDN-MAG/1969 tentang Pelaksanaan Tugas Aparatur Pemerintahan dalam Menjamin Ketertiban dan Kelancaran Pelaksanaan Pengembangan dan Ibadat Agama oleh Pemeluk-pemeluknya. Dalam pasal 4 ayat 1 dijelaskan bahwa pendirian rumah ibadah perlu mendapat izin dari kepala daerah atau pejabat pemerintah di bawahnya yang dikuasakan untuk itu. SK-SK bersama mengenai peraturan untuk mendirikan rumah ibadah itu hanya mengatur pendirian rumah ibadah

35 Gomar Gultom (ed), Dari SKB ke PBM (Jakarta: PGI, 2006), 10.

36 Ibid. 
untuk orang Kristen. ${ }^{37}$ Karena memang latar belakang dikeluarkannya SK tersebut karena ada gejala-gejala bahwa di beberapa daerah jumlah umat Kristen bertambah dengan pesat, dan di beberapa tempat terjadi perusakan terhadap gedung gereja. ${ }^{38}$ Berdasarkan latar belakang ini dapat dipahami bahwa peraturan tentang pendirian rumah ibadat tidak benar secara politiketik, karena kebijakan ini tidak mengakomodasi para pihak yang terkait langsung dengan peraturan tersebut, dan kaidah moralitas dalam pembuatan kebijakan. ${ }^{39}$

Secara manajemen, isi kebijakan PBM juga sulit untuk dilaksanakan, karena PBM menetapkan pemberian izin bukan hanya bergantung pada ketetapan pemerintah, tetapi juga ketetapan masyarakat. Penelitian terhadap pelaksanaan PBM ini justru menimbulkan permasalahan baru, karena masyarakat yang menganut pemahaman "menyetujui berdirinya sebuah gedung ibadah agama lain, sama saja dengan mengakui kebenaran agama lain atau menyangkali finalitas agamanya," tidak akan memberikan persetujuan hadirnya sebuah rumah ibadat dari agama lain, maka meskipun sebuah komunitas agama telah memenuhi aturan pemerintah yakni memiliki 90 anggota dewasa, jika tidak mendapatkan 60 tanda tangan dari masyarakat sekitar, maka izin pendirian rumah ibadat tidak akan pernah didapat. Isi rumusan PBM pendirian rumah ibadat jelas mendiskriminasikan komunitas agama tertentu yang tidak dapat memenuhi izin dari masyarakat setempat. Secara hukum, PBM juga tidak memberikan kepastian hukum terhadap pemberian izin pendirian rumah ibadat karena terdapat dualisme penetapan.

\footnotetext{
37 Simatupang, Membuktikan Ketidakbenaran Suatu Mitos (Jakarta: Pustaka Sinar Harapan, 1991), 240.

38 Ibid.

39 Riant Nugroho, Public Policy, 690.
} 


\section{Evaluasi Lingkungan Kebijakan}

Pemahaman terhadap lingkungan di mana kebijakan pendirian rumah ibadah dilaksanakan terlihat kurang mendalam. Pada masa awal kemerdekaan sebaran komunitas agama-agama di Indonesia sangat homogen. Namun dengan perpindahan penduduk yang terus terjadi, apalagi sering dengan telah majunya angkutan transportasi dan infrastruktur jalan, maka perpindahan penduduk yang terus berlangsung tersebut mengakibatkan daerah-daearah di Indonessia lebih heterogen. Kondisi tersebut membuat banyak daerah memiliki komposisi pemeluk agama yang sangat heterogean. Akibatnya, terdapat komunitas agama yang tidak dapat memiliki rumah ibadah karena jumlah komunitas agama itu belum mencukupi 90 orang dewasa, apalagi dengan banyaknya aliran dalam satu agama, tidak sedikit aliran komunitas agama tertentu tidak dapat memenuhi jumlah yang ditetapkan pemerintah tentang batas minimum jumlah jemaat untuk mendapatkan izin pendirian rumah ibadah. Dengan demikian jelaslah bahwa formulasi PBM tidak didasarkan pada analisis lingkungan kebijakan yang mendalam.

\section{Evaluasi Penerapan PBM}

Penerapan PBM tentang pendirian rumah ibadat sangat terkait dengan sosialisasi rumusan peraturan tersebut, demikian juga tersedianya faktor-faktor yang terkait dengan penerapan PBM, seperti birokrasi pemerintah sebagai pelaksana kebijakan, demikian juga kepala-kepala daerah, forum umat beragama, tokoh-tokoh agama. Akibat sosialisasi yang tidak memadai, maka pihak-pihak yang terkait dengan pendirian rumah ibadah sering tidak dapat melaksanakan mandat UUD 1945 dalam hal penyediaan fasilitas rumah ibadah. Tidak tersedianya faktor-faktor tersebut berakibat pada terabaikannya hak mendirikan tempat ibadah bagi komunitas agama-agama yang terdiskriminasikan. Gereja-gereja yang sedang mengurus izin atau belum memiliki izin tidak difasilitasi dengan baik untuk mendapatkan rumah ibadat yang menjadi hak komunitas agama tersebut, sebaliknya komponen-komponen yang terlibat dalam proses 
perizinan sebuah rumah ibadah justru menjadi penghalang.

Pendataan FKUB (Forum Komunikasi Umat Beragama) terhadap rumah ibadah di Kota Bekasi yang kemudian diterbitkan dalam sebuah buku berjudul "Rumah Ibadat di Kota Bekasi", yang disunting oleh Badruzzaman Busyani, dan diterbitkan oleh FKUB Bekasi, dan di dalamnya melaporkan rumah-rumah ibadah yang berizin, dan tak berizin di Kota Bekasi, khususnya gereja, menjadi tidak produktif, karena rekomendasi FKUB tidak menjamin diberikannya IMB terhadap sebuah gereja yang belum memiliki IMB, namun untuk mendapatkan IMB, sebuah gereja harus mendapatkan rekomendasi FKUB. Pendataan mengenai gereja-gereja yang memiliki IMB dan tidak memiliki IMB, yang kemudian dipublikasikan, mengakibatkan gereja-gereja yang tidak memiliki IMB, dan pada awalnya tidak mengalami gangguan masyarakat setempat, setelah publikasi itu justru mengalami gangguan dari oknum-oknum yang tidak bertanggung jawab.

Temuan ini menjelaskan bahwa PBM telah dijadikan alat untuk menutup tempat-tempat yang digunakan sebagai tempat ibadah tanpa memberikan alternatif rumah ibadat sebagai pengganti tempat yang tidak memiliki izin. Bahkan ketetapan PBM yang memberikan izin tempat ibadah sementara untuk sebuah komunitas beragama dapat memiliki tempat ibadah, sebelum memiliki tempat ibadah permanen, bukannya mendorong FKUB, birokrasi pemerintah untuk memfasilitasinya, tapi telah dijadikan alat untuk menutup tempat ibadat setelah waktu dua (2) tahun yang telah ditentukan.

Gerakan massa untuk menutup tempat-tempat ibadah yang tidak memiliki izin, atau sedang mengurus izin bahkan, mencabut izin pendirian rumah ibadat yang telah ada menunjukkan bahwa Peraturan Bersama Menteri tersebut tidak dipahami masyarakat dengan baik. Pada kasus-kasus terkait dengan penutupan, perusakan rumah ibadat pemerintah, dalam hal ini khususnya aparat kepolisian bertindak tidak netral, dan hampir tidak pernah ditemukan bahwa aktor-aktor penutupan dan perusakan rumah 
ibadat itu dihukum berat.

Beberapa tokoh gereja mengatakan, di Bekasi telah hadir kelompokkelompok radikal yang kehadirannya bertujuan menutup gereja-gereja yang tidak memiliki izin. Beberapa pemimpin gereja di Bekasi berpendapat bahwa publikasi FKUB sangat menolong kelompok-kelompok radikal untuk mendapatkan data gereja yang tidak berizin dan kemudian melakukan penutupan terhadap gereja tersebut, baik melalui intimidasi, pemanggilan pendeta setempat agar menutup gereja yang tidak berizin tersebut, bahkan tidak jarang penutupan gereja di Bekasi dilakukan dengan cara kekerasan apabila gereja tersebut tetap melakukan peribadatan di bangunan yang belum memiliki IMB gereja.

Keharusan mendapatkan izin masyarakat setempat untuk IMB rumah ibadat pada beberapa gereja justru menjadi kontraproduktif, karena telah menimbulkan koflik baru dalam masyarakat antaragama. Apalagi, pada individu atau kelompok-kelompok masyarakat tertentu, memberikan izin pendirian rumah ibadah yang berbeda agama, sama saja dengan mengkhianati agama mereka, karena membiarkan agama-agama yang berbeda berkembang dan mengancam perkembangan agama yang mereka anut. Realitas ini bukan hanya diakui oleh pemimpin-pemimpin gereja di Bekasi, tetapi juga tokoh-tokoh masyarakat di Bekasi, bahkan isu ini tersebar luas khususnya pada daerah-daerah di mana terjadi konflik terkait pendirian rumah ibadah.

Gereja di Bekasi harus menyusuri jalan panjang dalam pengurusan izin gereja. Bahkan ketika pembangunan gereja telah dilakukan, dan izin belum didapat, ada gereja yang dibakar massa. Pembangunan dapat dilakukan kembali setelah izin didapat. Sumber dari gereja POUK dan Gekari memberikan respon negatif terhadap PBM. Gereja Persekutuan Oikumene Umat Kristen (POUK) Graha Prima, pernah dibakar massa meskipun gereja tersebut berdiri di atas tanah yang disediakan pengelola Kompleks Perumahan Graha Prima Bekasi, dan diperuntukkan bagi rumah ibadah Kristen. Gereja tersebut harus bekerja keras melakukan pendekatan terhadap masyarakat. Melalui jalan yang cukup panjang akhirnya gereja itu 
bisa kembali dibangun, bahkan lengkap dengan plang nama gereja. Namun demikian, surat izin belum berhasil didapat. Hal yang sama juga dilakukan Gereja Gekari, pemimpin gereja dan jemaat terus-menerus mengadakan pendekatan sosial terutama ke tokoh-tokoh agama setempat. Akhirnya upaya ini berhasil juga, di mana keberadaan gereja bisa diterima oleh masyarakat, dan kepengurusan izin pun selesai. Di sini terlihat, regulasi masyarakat yang kerap bertentangan dengan aturan PBM mendapat tempat untuk menjadi instrumen penutupan rumah ibadah. Implementasi PBM tidak berdampak positif untuk mempermudah pendirian rumah ibadah.

Perizinan gereja yang dituangkan dalam PBM telah mengakibatkan beberapa gereja di Bekasi ditutup, seperti yang terjadi dengan HKBP, Gekindo, dan GPDI di Jati Mulya Bekasi, penutupan tersebut langsung dipimpin oleh camat setempat. Aturan keharusan adanya izin pemerintah telah melahirkan politisasi agama, di mana pejabat setempat memainkan agama, untuk menarik simpati pendukungnya, dan mempersulit atau menutup rumah ibadah yang berbeda dengan pendukungnya adalah jalan politisasi agama yang sangat berbahaya bagi keutuhan bangsa Indonesia.

Apabila dalam SKB Dua Menteri perizinan bergantung pada kepala daerah, dan ini pun terbukti dimanfaatkan untuk kepentingan individu atau kelompok tertentu, maka syarat yang lebih detail tentang pendirian rumah ibadah justru menjadi lebih pelik. Pada daerah-daerah tertentu di Bekasi dijumpai, bahwa keharusan mendapatkan izin dari masyarakat setempat justru menimbulkan konflik baru dalam masyarakat. Individu atau kelompok masyarakat yang sebelumnya tak peduli dengan kehadiran rumah ibadah yang berbeda dengan agama yang mereka anut, kemudian secara tidak langsung merasa dipaksa untuk peduli dengan menyetujui kehadiran rumah ibadah agama yang berbeda. Permintaan persetujuan individu-individu yang berdomisili di sekitar rumah ibadah yang akan didirikan membuat penganut agama lain merasa dipaksa untuk menyetujui kehadiran rumah ibadah agama lain, padahal pada sisi yang lain, tokohtokoh agama tertentu mengajarkan bahwa adalah haram untuk 
mengizinkan hadirnya sebuah rumah ibadah agama lain. Jadi pendirian rumah ibadah, bukan lagi ditujukan pada pemenuhan hak beribadah umat beragama, tapi bergantung pada izin masyarakat.

Birokrasi yang amat panjang dalam pendirian gereja, telah membuat gereja-gereja di Bekasi harus menyusuri jalan panjang dalam pendirian gereja. Birokrasi yang panjang tersebut juga kemudian melahirkan mafiamafia dalam pengurusan gereja. Repotnya, mafia-mafia pengurusan izin gereja ini juga melibatkan pemerintah. Hal itu sebenarnya sudah dapat diprediksi, karena dalam PBM ada dua regulasi yang harus dipenuhi dalam pengurusan izin gereja, yakni regulasi pemerintah dan regulasi masyarakat. Mafia-mafia dalam pengurusan izin gereja ini bisa hadir dari pemerintah dengan birokrasinya, dan juga di masyarakat. Birokrasi yang panjang ini malah mengakibatkan gereja harus mengeluarkan biaya yang lebih besar, dan itu juga yang menyebabkan pengurusan izin gereja memerlukan waktu yang amat panjang. Di Bekasi, pengurusan izin tercepat berlangsung selama dua tahun.

Berdasarkan hasil penelitian di atas jelaslah bahwa dalam perspektif gereja-gereja di Bekasi, PBM tidak produktif dan implementasinya berdampak buruk dalam kehidupan antaragama di Bekasi. PBM terbukti dimanfaatkan kelompok-kelompok diskriminatif untuk menutup rumahrumah ibadah. Padahal ada banyak rumah ibadah yang telah berdiri cukup lama, dan diterima baik oleh masyarakat, namun dengan memperalat peraturan yang bersifat diskriminatif itu, rumah-rumah ibadah itu pun mengalami gangguan. Beberapa di antaranya bahkan tutup dan pindah tempat. Dari berbagai fakta itu, terbuktilah bahwa PBM 2006 memberikan legitimasi terhadap tindakan diskriminatif. PBM juga terbukti telah menghalangi hak komunitas agama untuk memiliki tempat beribadah.

\section{Evaluasi Dampak Penerapan PBM}

Penerapan PBM bukan hanya membatasi hak komunitas agama untuk memiliki tempat ibadat, namun penerapan PBM justru pada beberapa tempat ditemukan telah meningkatkan intoleransi agama. Kebijakan 
diskriminatif akan menyuburkan intoleransi antaragama. Penerapan PBM yang didasarkan pada kebebasan beragama dan kebebasan komunitas agama untuk memiliki rumah ibadat dan juga kerukunan antarumat beragama tidak tercapai. Tujuan PBM tidak tercapai karena dalam isi rumusan peraturan tersebut terdapat kontradiksi, dan sosialisasi yang kurang memadai telah berdampak buruk dalam kehidupan masyarakat. Apabila tujuan PBM adalah untuk menciptakan kerukunan antarumat beragama maka temuan penelitian menunjukkan bahwa tujuan tersebut tidak tercapai. Komunitas agama yang menjadi sasaran kebijakan PBM tidak dapat menikmati haknya untuk memiliki tempai ibadat karena komponenkomponen yang terkait dengan perizinan rumah ibadat belum memahami PBM dengan baik.

\section{Kesimpulan}

Berdasarkan evaluasi rumusan PBM tentang pendirian rumah ibadah dapat dipahami bahwa PBM memiliki landasan hukum pada UUD 1945 secara khusus pasal 29 tentang perlindungan kebebasan beragama dan beribadah. Karena itu petunjuk pelaksanaan pendirian rumah ibadah itu semestinya isinya harus melindungi hak beribadah warga negara Indonesia, baik secara pribadi maupun secara berkelompok. Namun, perumusan PBM tidak melibatkan semua pemangku kepentingan, dalam hal ini komunitas agama yang memiliki hak mendirikan tempat ibadah. Dengan demikian maka dapat dipahami bahwa perumusan PBM tidak memenuhi syaratsyarat sebuah kebijakan publik dalam sebuah negara demokratis seperti Indonesia. Model perumusan yang tidak tepat ini berakibat pada perumusan kebijakan yang diskriminatif, karena tidak semua pemangku kepentingan terlibat dalam perumusan peraturan tersebut. Akibatnya pelaksanaan PBM tidak memenuhi tujuan yang diharapkan yakni untuk memfasilitasi umat beragama memiliki tempat ibadah dan menjaga kerukunan umat beragama. 
Berdasarkan Pancasila dan UUD 45, dokumen DUHAM 1948, Kovenan Internasional Hak-Hak Sipil dan Politik, dokumen Deklarasi untuk Mengeliminasi Segala Bentuk Praktik Intolernasi dan Diskriminasi Berdasarkan Agama dan Kepercayaan (Declaration on Elimination of All Forms Intolerance and Discrimination Based on Religion or Belief). Dokumen Deklarasi untuk Melindungi Hak-hak Individu Minoritas untuk bidang nasionalitas/Etnis, Agama, dan Bahasa (Declaration on the Rights of Persons Belonging to National or Ethnic, Religious and Linguistic Minorities). Jelaslah bahwa rumusan PBM bersifat diskriminatif dan telah merampas hak masyarakat untuk mendirikan rumah ibadah yang dijamin oleh undang-undang di atasnya, dalam hal ini UUD 1945.

\section{Rekomendasi}

Penerapan PBM tentang pendirian rumah ibadat ini direkomendasikan dihentikan karena isinya tidak memenuhi kriteria kebijakan yang benar dalam proses perumusan kebijakan, yakni tidak dilakukan dengan melibatkan semua stakeholder dalam hal ini komunitas agama yang berkepentingan dengan izin pendirian rumah ibadat. Rumusan isi PBM tidak dilandasi Undang-Undang Dasar 1945 yang mengakui kebebasan beragama dan kebebasan beribadat. Dalam rumusan PBM terdapat dualisme ketetapan perizinan rumah ibadat, yakni berdasarkan ketetapan pemerintah serta berdasarkan kehendak masyarakat sekitar. Formulasi PBM tidak tepat secara politik-etik karena tidak mengakomodasi pihak yang terkait secara langsung dengan kebijakan pendirian rumah ibadat. Secara manajemen, isi kebijakan pendirian rumah ibadat sulit untuk dilaksanakan karena adanya dualisme otoritas, yakni antara otoritas pemerintah dan otoritas komunitas masyarakat tertentu.

Secara bahasa juga tidak jelas karena pemberian izin rumah ibadah sementara dalam jangka waktu dua tahun tidak dijelaskan berapa kali perizinan penggunaan rumah ibadah sementara yang telah habis waktunya, akibatnya setelah habis rentang waktu pemberian izin penggunaan tempat ibadah sementara, komunitas agama tersebut mengalami kesulitan untuk 
memperpanjang izin menggunakan rumah ibadah sementara, bahkan tidak jarang harus ditutup dengan alasan tidak mendapatkan izin pendirian rumah ibadah. Terkait dengan kebebasan beribadat seharusnya izin penggunaan tempat ibadah sementara tersebut tidak berbatas waktu. 